\title{
Conception of Ageing: Perspective of the Young and the Elderly
}

\author{
Ms. Tanya Sharma ${ }^{1 *}$
}

\section{ABSTRACT}

'Ageing' is a multidimensional process of physical, psychological, and social change. There occurs systematic stereotyping and discrimination against people because they are old. Ageist attitudes may perpetuate in many ways leading to a variety of psychological consequences. The present study aims to explore qualitatively; myths, attitudes and stereotypes towards old age. A sample of 10 participants was selected; five each from the age group of 18 to 30 years and 65 to 85 years, semi-structured interviews were conducted and the data was subjected to thematic analysis. Findings indicate certain commonalities and differences in the ways the two agevarying groups perceive ageing which has an implication on the relationship between the two groups.

Keywords: Ageing, Health, Stereotype.

Ageing primarily refers to a progression of physical decline, a change in family roles (e.g., becoming a grandparent), a change in work status (retirement), or forgetting where you left your keys. The World Health Organization (WHO) considers old age starting at the age of 65. By 2025, the world's population is expected to include more than 830 million people at an age of 65 (WHO, 2011). With a comparatively young population, India is still poised to become home to the second largest number of older persons in the world.

Holding a prejudice against people who are aged is one form of ageism. Ageist attitudes are perpetuated in many ways, for example, the lack of positive images of the elderly in advertisements and on television programs. Businesses frequently reinforce ageist stereotypes by not hiring or promoting older workers even when they are physically and mentally fit. Underlying these attitudes are myths and stereotypes about old age which are entrenched in almost all the societies. The most common negative myths and stereotypes about ageing are illness, poverty, ugliness, mental decline, uselessness, powerlessness, poverty, isolation. Negative stereotyping may result in acceptance, denial, avoidance, or reform (Palmore, 1990) all of which may have harmful effects. For example, an elderly person who accepts the negative

\footnotetext{
${ }^{1}$ M. Phil. Assistant Professor, Department of Clinical Psychology, Central Institute of Psychiatry, Ranchi *Responding Author (C) 2016 I T Sharma; licensee IJIP. This is an Open Access Research distributed under the terms of the Creative Commons Attribution License (http://creativecommons.org/licenses/by/2.0), which permits unrestricted use, distribution, and reproduction in any Medium, provided the original work is properly cited.
} 


\section{Conception of Ageing: Perspective of the Young and the Elderly}

image may "act old" even though this may be out of keeping with their personality or previous habits. They may stop or reduce social activities, not seek appropriate medical treatment, or accept poverty. In essence, this internalization of a negative image can result in the elderly person becoming prejudiced against him/her, resulting in loss of self-esteem, self-hatred, shame, depression, and/or suicide in extreme cases.

Positive stereotypes about aging are also held by some people that are usually far less damaging than negative stereotypes. However, positive stereotyping such as considering them a source of wisdom and dependable could also be a source of exploitation. For instance, these days there is a trend among young working couples to leave their children and homes under the supervision of elderly in the family. While, there is no harm in doing so, often the elderly members of the family are overburdened and may feel loss of personal freedom. In many cases, they may not even come to realize it.

\section{METHOD}

A total of ten participants were included in the sample. Five participants were in the age group of 18 to 30 years and the other five participants belonged to the age group of 65 to 85 years. The participants were residents of Delhi and adjoining areas hailing from middle socioeconomic status of urban area. A semi-structured in-depth interview was conducted to investigate participant's attitudes, myths and stereotypes about old age. The interview conducted with the participants were recorded and transcribed followed by thematic analysis (Denzin \& Lincoln, 2011).

\section{RESULTS AND DISCUSSION}

\section{Deterioration of the body}

Most significant characteristic of old age is perceived to be deterioration in physical strength and vigour. Younger participants seem more concerned with deteriorating physical appearance than an increased susceptibility to illness perceived by the elderly participants.

\section{Table 1: Deterioration of the body}

\begin{tabular}{|c|c|}
\hline Young participants & Elderly participants \\
\hline $\begin{array}{l}\text { “Lack of energy”, “looks gone”, } \\
\text { “wrinkles”, “tooth loss”, “weak organs, } \\
\text { and bones”, “hormone change”. } \\
\text { "Health problems”, “deteriorating physical } \\
\text { strength and vigour.” }\end{array}$ & $\begin{array}{l}\text { "Body ache, illness, health problems” } \\
\text { “Weak body, pain in joints, hands, legs, } \\
\text { can’t do things properly, can’t walk” } \\
\text { "Physical decline, weakening body is the } \\
\text { worst aspect of old age”. }\end{array}$ \\
\hline
\end{tabular}




\section{Perceived interference versus neglect}

Participants from the younger age group feel that in old age people become stubborn, interfering and have rigid views. Participants from the elderly group feel that in old age there is a lot of free time spent rather lonely.

\section{Table 2: Perceived lack of concern versus interference}

\begin{tabular}{|l|l|}
\hline \multicolumn{1}{|c|}{ Young participants } & \multicolumn{1}{|c|}{ Elderly participants } \\
\hline “Their view points are difficult to change” & "No listeners and followers." \\
“Think a lot about children's lives and put & "Children don't care" \\
their own values in their children's lives" & "Children do not respect, they disobey" \\
& "Feel lonely and need people to talk to" \\
\hline
\end{tabular}

\section{Decreased responsibility and availability of spare time}

Participants in both the young and the elderly group believe that availability of spare time is a benefit in old age. However, young participants consider material benefits like pension; concessions in travel etc. as comforts in old age while the elderly consider belongingness to be more important.

Table 3: Decreased responsibility and availability of spare time

\begin{tabular}{|l|l|}
\hline \multicolumn{1}{|c|}{ Young participants } & \multicolumn{1}{|c|}{ Elderly participants } \\
\hline “Concession in transport, pension” & $\begin{array}{l}\text { "Spare time at disposal.” } \\
\text { "Only if children are around, if they care and } \\
\text { "More leisure time" } \\
\text { "Less work }\end{array}$ \\
\hline
\end{tabular}

4. Myths about old age

Both the young and the elderly believe that it is a myth that aged people are not concerned about their physicality. Young participants also believe that it is a myth that all aged people are invariably eccentric or irritable. Elderly participants believe that considering elderly as incompetent and burdensome is also a myth.

Table 4: Myths about old age

\begin{tabular}{|l|l|}
\hline \multicolumn{1}{|c|}{ Young participants } & \multicolumn{1}{|c|}{ Elderly participants } \\
\hline $\begin{array}{l}\text { "Retired people become lethargic, they are less } \\
\text { interested in their looks, and older people gain } \\
\text { weight, become crankier". }\end{array}$ & $\begin{array}{l}\text { "Children think old people are weak who } \\
\text { cannot give adequate advice and that they are } \\
\text { no less than a burden.” }\end{array}$ \\
\hline
\end{tabular}




\section{Conception of Ageing: Perspective of the Young and the Elderly}

Literature shows that young people hold more negative attitude for the aged compared to the aged themselves. Sharma and Bhandari (1970) found that college students hold predominantly negative attitude and beliefs about ageing and aged such as old people are inactive. In the present study also, negative attitude for the elderly are evident among the youth. Old people are considered rigid, stubborn and excessively interfering. Furthermore, Sharma (2002) reported that younger people think that caring of older persons snatches their leisure time. This is also evident in the findings of the present study. Young participants do believe that there is over-involvement of parents, in their old age, in children's lives which is perceived as rather interference thereby killing their personal time.

Prakash (1992) examined attitudes of Indian subjects towards the elderly people and compared to that of British and Canadian subjects. Indian subjects were found to attribute blame to the elderly for their poor health and low income in old age. In the present study, this is evident as a myth that exists among the youth. On the contrary, it was found in the present study that Indian youth consider monetary benefits like pension or concession as an advantage in old age along with lesser responsibility and relatively free time to enjoy.

Anantharaman (1984) found that negativity was greater among older people with respect to variables such as insecurity. A primary concern for the elderly is their deteriorating physical health and also financial condition owing to retirement making them insecure about their future especially if lack of support is perceived from the side of their children.

A significant and repetitive finding in the study is a perception among the elderly that they are rendered unworthy and weak in old age. Lena et al (2009) in a cross sectional study; have shown that the elderly have a negative attitude towards old age as they feel neglected. In the present study also, the theme of neglect is evident in the account of elderly participants. Though, the elderly do not think as negative of themselves as the young do; they do, however feel that old age is not a good time of life as they are considered by children as worthless and are thus, neglected.

\section{CONCLUSION}

The present study puts forth attitudes, beliefs and stereotypes of both, the young and the elderly in an urban Indian setting regarding ageing and old age. Similarities exist regarding physical decline accompanies old age. Differences exist in terms of perceived involvement. While the elderly feel that they are neglected; the young feel that the aged tend to get stubborn and rigidly over-involved. Perceived neglect is significant among elderly while reduced responsibility and spare time are perceived as advantages among the youth.

\section{FUTURE DIRECTIONS}

This is a general comparison of the beliefs and stereotypes the two age- varying groups hold about ageing and old age. Further researches may focus on more specific themes. The study has 
implications in understanding and reducing the disparities in the attitude, thereby strengthening the relationship.

\section{REFERENCES}

Anantharaman, R.N. (1984). Perception of stereotypes toward old age by two generations. Journal of Psychological Researches, 28, 170-173

Denzin, N.K. \& Lincoln, S.Y. (2011). The Sage Handbook of Qualitative Research (4th Ed). Thousand Oaks, CA: Sage

Lena, A., Ashok, K., Padma, M., Kamath, V., Kamath A. (2009) Health and social problems of the elderly: A cross-sectional study in Udupi Taluk, Karnataka. Indian Journal of Community Medicine, 34,131-4.

Palmore, E. (1990). Ageism: Negative and positive. New York: Springer.

Prakash, I.J. (1992). Attitudes towards helping elderly people: An Indian Study. Indian Journal of Gerontology, 6, 44-50

Sharma, K.L. \& Bhandari , P.:( 1970) A study of student’s stereotypes towards ageing. Indian Journal of Gerontology, 2, 20-27

Sharma, K.L. (2002). Images of Ageing. Indian Journal of Gerontology, 16, 286-297

World Health Organization (WHO) and United States National Institute on Aging (U.S. NIA) eds. (2011). Global Health and Aging. Retrieved from http://www.who.int/ ageing/ publications/global_health/en/ 